\title{
EFFECT OF ANTI-BROWNING AGENTS AND WRAPPING FILMS ON BROWNING INHIBITION AND MAINTAINING QUALITY OF BABY CORN DURING STORAGE. \\ Attia, Manal M. ${ }^{1}$; S. M. M. Saleh ${ }^{2}$ and E. M. El-Shabrawy ${ }^{3}$ \\ ${ }^{1}$ Postharvest and Handling of Vegetable Crops Dept. Horticulture Res. Inst., Agric. Res. Center, Giza, Egypt. \\ ${ }^{2}$ Central Laboratory for Agric. Climate, Agric. Res. Center (ARC), Egyptian Ministry of Agric. \\ ${ }^{3}$ Plant Pathology Res. Inst., Agric. Res. Center (ARC).
}

\begin{abstract}
An experiment was carried out at Kaha Experimental Station, Kalubia Governorate, during 2009 and 2010 seasons, to study the influence of anti-browning agents (ascorbic acid 1\% and calcium chloride at 1\%) and wrapping films (polypropylene and stretch ) on reducing browning, maintaining quality and inhibiting pathogens of baby corn (Zea mays L )ears 321 Tribal hybrid (TH). All studied treatments reduced weight loss, browning, poly phenol oxidase (ppo) activity, total microbial count and the loss of total sugars comparing with untreated (control) treatment.

However, dipping baby corn ears in ascorbic acid (AA) at $1 \%$ or calcium chloride at $1 \%$ then wrapped with polypropylene film was the most effective treatments in this concern. Baby corn ears treated with $1 \%$ ascorbic acid (AA) or $1 \%$ $\mathrm{Cacl}_{2}$ then wrapped with polypropylene film did not exhibit any changes in their appearance till $12^{\text {th }}$ day of storage of $5^{\circ} \mathrm{C}$ and gave good appearance at the end of storage (15 days), while untreated ears resulted in poor appearance after 9 days of storage.
\end{abstract}

\section{INTRODUCTION}

Baby corn or young - ear corn (Zea mays L) is widely cultivated throughout the world. Baby corn may be produced from sweet corn or field corn, but sweet corn seeds still highly cost compared to the field corn hybrids. Plants are harvest early while ears are very small and immature (1 to 3 days) after silk become visible (Wang et al., 2010). It is the entire young cob, which has high nutritional value. Baby corn is cultivated in Egypt for fresh market or for processing exportation market especially in United Kingdom and became an important vegetable for exportation. One of the major postharvest problems in baby corn is the development of browning after harvest (Meenaphan, 2003). Browning occurs in many fruits and vegetable species and the mechanisms underlying the process may be either enzymatic or non enzymatic factors (Martinez and Whitaker, 1995). Browning of baby corn occurred at the tip of the immature ovules, cut surface of the cobs and silks which remain attached to the cob. Browning is the main limiting factor of baby corn quality, which results in rejection by the consumer. Oxidation of phenolic compound is the cause of browning in plant tissues (Mayer and Harel, 1991; Martinez and Whitalcer, 1995). 
Attia, Manal M. et al.

Among the compounds that have been shown to inhibit browning as postharvest treatment are ascorbic acid (AA) and calcium chloride ( $\mathrm{Cacl}_{2}$ ) which are natural identical anti-browning agents and generally recognized as safe (Son et al.,2001; Lee et al.,2003, Gonzalez- Aguilar et al.,2004).

Dipping baby corn ears in solution of ascorbic acid or $\mathrm{Cacl}_{2}$ reduced browning and extend shelf life during storage (Meenaphan, 1995; Kelen et al., 2005). Also fresh baby corn ears are perishable food product prone to fast postharvest deterioration caused by moisture loss, husk discoloration and development of pathogens. Wilted husk and yellowing limit the shelf life of fresh baby corn to $3-5$ days at $10^{\circ} \mathrm{C}$ (Hardenburg et al., 1986).

Keeping cobs in modified atmosphere may reduce the mold growth, controlled the exponential growth of micro organisms and inhibit sugar and chlorophyll loss (Rodov et al., 2000). Deak et al., (1987) reported that shrink wrapping of sweet corn in bags and storing it at $1{ }^{\circ} \mathrm{C}$ reduced the changes associated with senescence and postharvest deterioration relative to non wrapped samples. Risse and McDonald (1990) found that wrapped corn appeared freshe, less dried and maintained TSS content than non wrapped corn. Also, (Radov et al., 2000) found that CA films ensure freshness and crispness of sweet corn by reducing the water loss which leads to reduction in wilting and dehydration.

The objective of this study was to determine the effect of antibrowning agents and wrapping film on reducing browning, maintaining quality and inhibiting of pathogens during storage.

\section{MATERIALS AND METHODES}

Baby corn (Zea Mays L) 321 Triple Hybrid (TH) (field corn type) was grown at Kaha Experimental Station, Kalubia, Governorate during the two successive seasons of 2009 and 2010 . Seeds were sown on $15^{\text {th }}$ and $17^{\text {th }}$ of August in the first and second seasons, respectively. Planting spaces were $90 \mathrm{~cm}$ between rows and $10 \mathrm{~cm}$ between hills at the same row. Normal cultural practices were carried out whenever it was needed according to the recommendation of Ministry of Agriculture. Young - ear corn, was individually harvested as soon as silk emerged (90 days from planting), then were transported under cooling to the laboratory of Handling of Vegetable Crops Department. Husks and silks were removed manually and uniform ears in size $(8-10 \mathrm{~cm}$ in length and 1- 1.5 in base diameter), color and free from injury were selected. Ears were divided into 7 groups and some anti-browning agents and wrapping film were applied as follows:

1. Dipping in solution of ascorbic acid at $1 \%$ and then wrapping with polypropylene film $\left(T_{1}\right)$.

2. Dipping in solution of $\mathrm{Cacl}_{2}$ at $1 \%$ then wrapping with polypropylene film (T2).

3. Dipping in distilled water, then wrapping with polypropylene film ( $\left.T_{3}\right)$

4. Dipping in solution of ascorbic acid at $1 \%$ then wrapping with stretch film $\left(\mathrm{T}_{4}\right)$. 
5. Dipping in solution of $\mathrm{Cacl}_{2}$ at $1 \%$ and then wrapping with stretch film ( $\left.\mathrm{T}_{5}\right)$.

6. .Dipping in distilled water, then wrapping with stretch film ( $\left.T_{6}\right)$.

7. Control (without treatment) $T_{7}$.

Ears for each treatment dipped for $5 \mathrm{~min}$. and then air dried. Twenty four replicates were prepared from each treatment. Each replicate consisted of 10 ears placed in polystyrene tray (Teckpack NAIROP, $5^{\star} 70$ inch PET (Italy). and then wrapped with polypropylene films $(20 \mu \mathrm{c})$ or stretch $(0.09 \mu \mathrm{c})$. The samples were arranged in complete randomized design and stored at 5 ${ }^{\circ} \mathrm{C}$ and $95 \% \mathrm{RH}$ for 15 days. Samples were taken at random in three replicates. Measurements were taken immediately after treatment and every three - day intervals.

The following parameters were recorded:

1. Weight loss percentage was estimated according to the following equation:

Weight loss $\%=$ initial fruit weight - fruit weight at sampling date / initial fruit weight * 100 .

2. General appearance $(\mathrm{GA})$ was evaluated using scale from 9 to 1 , where $9=$ excellent, $7=$ good, $5=$ fair, $3=$ poor, $1=$ unusable, and cobs rating below 5 were considered unmarketable.

3. Browning of young ear corn. was assessed on a $0-4$ scale, where 0 was considered no browning development and 4 was sever browning development (Meenaphan, 2003).

4. External surface color was evaluated by a color difference meter (Minolta $C R 200$ ) to measure the $L$ and $b$ values.

\section{Total phenol contents:}

Dry defeated crushed baby corn ears $(1.0 \mathrm{~g})$ were macerated in $5-10$ $\mathrm{ml} 80 \%$ ethanol for at least 24 hours at $0{ }^{\circ} \mathrm{C}$. The remaining residue was reextracted with $5-10 \mathrm{ml}$ ethanol three times using $80 \%$ ethanol. The phenolic content was determined by the colorimetric modified method using FolinCiocalteu reagent. The reagent was diluted (1:10 with distilled water) then $0.75 \mathrm{ml}$ was added to the extracts $(0.1 \mathrm{ml})$ in test tubes. The mixture was mixed and allowed to stand at room temperature for $5 \mathrm{~min}$. then $0.75 \mathrm{ml}$ of $6 \%(\mathrm{w} / \mathrm{v})$ sodium carbonate solution was added and mixed. After $90 \mathrm{~min}$. at room temperature, the absorbance was recorded at $765 \mathrm{~nm}$. The standard curve was prepared by gallic acid $(0-250 \mathrm{mg} / \mathrm{L}$ in aqueous methanol $(50 \%)$. The total phenols were expressed as chlorogenic acid equivalents (mg / $100 \mathrm{gm}$ fresh weight) AOAC (1990).

Polyphenol oxidase (ppo) assay:

The poly phenol oxidase (ppo) was extracted by homogenizing treated or untreated vegetable samples with 1-5 fold their weight sodium phosphate buffer $(0.1 \mathrm{~m}, \mathrm{pH}$ 6.5) containing $30 \mathrm{mM}$ sodium ascorbate and $0.4 \mathrm{M}$ sucrose at $25^{\circ} \mathrm{C}$. The crude extraction was filtered and refrigerated till used within $24 \mathrm{~h}$

Catechol as substrate $(3 \mathrm{~mL}, 10.0 \mathrm{mM})$ dissolved in the phosphate buffer was mixed with $1.0 \mathrm{Ml}$ enzyme extract. All of the enzymatic reactions were kept at the optimum condition (substrate saturation, $\mathrm{pH} 6.5$ and $25^{\circ} \mathrm{C}$.) 
Attia, Manal M. et al.

The increase in absorbance of 0.01 per min. at $495 \mathrm{~nm}$ at the specified condition was defined as one unit of ppo activity. The results were expressed as percentage of the activity of the respective zero experiment (Dogan et al.,2002)

Microbiological analysis:

Each sample was prepared by homogenizing $10 \mathrm{gm}$ of sliced baby corn with $100 \mathrm{ml}$ sterile 0.1 peptone water for $2 \mathrm{~min}$. Dilution by 0.1 pepton water was made as needed in Plate Count Agar (PCA) and incubated for $24 \mathrm{hr}$ at $37{ }^{\circ} \mathrm{C}$ for the determination of meso-sphilic aerobic microorganisms. Viable counts were determined by counting the number of colonies and reported as colony forming units per gram, CFU / g (Anese and Nicoli, 1997) (1974).

Total sugars were measured according to Somogyi (1952) and Nelson

All data were subjected to the statistical analysis according to the method described by Senedecor and Cochran (1980).

\section{RESULTS AND DISCUSSION}

\section{Weight loss:}

Data in Table (1) showed that weight loss percentage of baby corn ears increased by the prolongation of the storage period. This might be due to the loss in moisture through transpiration and loss in dry matter through respiration process (Attia, 2006). Robinson et al. (1975) found that, the daily average weight loss, mainly due to loss in water, on baby corn was high compared with other commodities. Moreover, dipping baby corn ears in solution of ascorbic acid (AA) or $\mathrm{Cacl}_{2}$ and then wrapping with different films proved to be superior in reducing weight loss percentage significantly as compared with distilled water treatment and untreated control; $\mathrm{Cacl}_{2}$ treatment at different wrapping films being the most effective in this concern. Untreated (control) gave the highest value in weight loss percentage. Burton (1982) showed that the surface of young - ear corns is covered with very small ovules resulting in large surface area unit per volume, which increase weight loss during storage.

These results are in agreement with those obtained by Meenaphan (1995) who found that $\mathrm{Cacl}_{2}$ treatment might reduce respiration rate of the ears and inhibited the physiological processes, which in turn reduced weight loss. These results are in agreement with those reported by Risse and McDonald (1990) and Rodov et al.(2000), they noted that wrapping ears with different films provide an excellent hinder against moisture loss. Also, modification of the atmosphere around the ears, in other words, decreasing $\mathrm{O}_{2}$ and increasing $\mathrm{CO}_{2}$ in the storage atmosphere of ears, decreases the rate of respiration.

As to the interaction between treatments and storage period, data revealed that the lowest value of weight loss at the end of storage period (15 
days) was noted in baby corn ears treated with $\mathrm{Cacl}_{2}$ and wrapped with different films.

Table (1): Effect of anti-browning agents and wrapping films on weight loss \% of baby corn ears during storage in 2009 and 2010 seasons.

\begin{tabular}{|c|c|c|c|c|c|c|c|}
\hline \multirow{2}{*}{$\begin{array}{l}\text { Treatments } \\
\text { (T) }\end{array}$} & \multicolumn{7}{|c|}{ Storage period(s)/ (days) } \\
\hline & 0 & 3 & 6 & 9 & 12 & 15 & Mean \\
\hline \multicolumn{8}{|c|}{2009 season } \\
\hline T1 & 0.00 & 0.10 & 0.32 & 0.55 & 0.82 & 1.00 & 0.56 \\
\hline T2 & 0.00 & 0.06 & 0.11 & 0.25 & 0.32 & 0.45 & 0.24 \\
\hline$\overline{T 3}$ & 0.00 & 0.17 & 0.52 & 0.64 & 1.13 & 1.11 & 0.71 \\
\hline T44 & 0.00 & 0.12 & 0.38 & 0.62 & 0.94 & 1.12 & 0.64 \\
\hline T5 & 0.00 & 0.08 & 0.19 & 0.34 & 0.48 & 0.65 & 0.35 \\
\hline T6 & 0.00 & 0.20 & 0.59 & 0.79 & 1.25 & 1.24 & 0.81 \\
\hline T7 & 0.00 & 2.21 & 4.38 & 7.42 & 9.37 & 11.74 & 7.02 \\
\hline Mean & 0.00 & 0.42 & 0.93 & 1.52 & 2.04 & 2.47 & 1.48 \\
\hline LSD at $0.05 \%$ level & \multicolumn{2}{|c|}{$\mathrm{T}=0.12$} & \multicolumn{2}{|c|}{$\mathrm{S}=0.15$} & \multicolumn{2}{|c|}{$T^{*} \mathrm{~S}=0.17$} & \\
\hline \multicolumn{8}{|c|}{2010 season } \\
\hline $\mathbf{T} 1$ & 0.00 & 0.13 & 0.26 & 0.42 & 0.68 & 0.78 & 0.45 \\
\hline T2 & 0.00 & 0.05 & 0.11 & 0.19 & 0.30 & 0.45 & 0.22 \\
\hline T3 & 0.00 & 0.21 & 0.42 & 0.69 & 0.92 & 1.24 & 0.70 \\
\hline T4 & 0.00 & 0.25 & 0.34 & 0.53 & 0.79 & 0.98 & 0.58 \\
\hline T5 & 0.00 & 0.11 & 0.21 & 0.29 & 0.42 & 0.53 & 0.31 \\
\hline T6 & 0.00 & 0.32 & 0.54 & 0.97 & 1.11 & 1.42 & 0.87 \\
\hline T7 & 0.00 & 2.48 & 5.11 & 8.32 & 9.71 & 11.94 & 7.51 \\
\hline Mean & 0.00 & 0.51 & 1.00 & 1.63 & 1.99 & 2.48 & 1.52 \\
\hline LSD at $0.05 \%$ level & \multicolumn{2}{|c|}{$\mathrm{T}=0.17$} & \multicolumn{2}{|c|}{$\mathrm{S}=0.19$} & \multicolumn{2}{|c|}{$\mathrm{T}^{*} \mathrm{~S}=0.21$} & \\
\hline
\end{tabular}

T1= Dipping in ascorbic acid at 1\% +polypropylene film.

T2=Dipping in $\mathrm{Cacl}_{2}$ at $1 \%$ then polypropylene film.

T3=Dipping in distilled + polypropylene film

T4=Dipping in ascorbic acid at $1 \%+$ stretch film

T5=Dipping in $\mathrm{Cacl}_{2} 1 \%+$ stretch film

T6=Dipping in distilled water+ with stretch film.

T7=Control (without treatment)

\section{General appearance (GA):}

Data in Table (2) indicate that GA of baby corn ears was deteriorated during storage. The decrease of GA during storage period might be due to morphological defects, such as dryness, change in color, browning or decay (Rodov et al., 2000).

General appearance of baby corn ears treated with ascorbic acid at $1 \%$ or $\mathrm{Cacl}_{2}$ at $1 \%$ and then wrapped with polypropylene film did not exhibit any changes in their appearance till the $12^{\text {th }}$ day of storage at $5^{\circ} \mathrm{C}$ and gave ears with good appearance at the end of storage (15 day). However, dipping ears in anti-browning agent and then wrapped with stretch film reflected fair appearance. On the other hand, untreated ears (control) resulted in poor appearance after 9 days of storage. Meenaphan (2003) found that the keeping quality of baby corn ears by using AA or Cacls could be attributed to 
Attia, Manal M. et al.

the effect of these treatments on the reduction of weight loss, browning and microbial rot of the ears.

Table (2): Effect of anti-browning agents and wrapping films on general appearance (score) of baby corn ears during storage in 2009 and 2010 seasons.

\begin{tabular}{|c|c|c|c|c|c|c|c|}
\hline \multirow{2}{*}{$\begin{array}{l}\text { Treatments } \\
\text { (T) }\end{array}$} & \multicolumn{7}{|c|}{ Storage period(s)/ (days) } \\
\hline & 0 & 3 & 6 & 9 & 12 & 15 & Mean \\
\hline \multicolumn{8}{|c|}{2009 season } \\
\hline $\mathbf{T 1}$ & 9.00 & 9.00 & 9.00 & 9.00 & 8.33 & 7.67 & 8.67 \\
\hline T2 & 9.00 & 9.00 & 9.00 & 9.00 & 8.33 & 7.00 & 8.56 \\
\hline T3 & 9.00 & 9.00 & 9.00 & 7.00 & 5.00 & 3.67 & 7.11 \\
\hline T4 & 9.00 & 9.00 & 9.00 & 8.33 & 7.00 & 5.00 & 7.89 \\
\hline T5 & 9.00 & 9.00 & 9.00 & 8.33 & 7.00 & 5.00 & 7.89 \\
\hline T6 & 9.00 & 9.00 & 8.33 & 6.33 & 4.33 & 3.00 & 6.67 \\
\hline T7 & 9.00 & 9.00 & 7.00 & 3.67 & 3.00 & 1.00 & 5.44 \\
\hline Mean & 9.00 & 9.00 & 8.62 & 7.38 & 6.14 & 4.62 & 7.46 \\
\hline LSD at $0.05 \%$ level & \multicolumn{2}{|c|}{$\mathrm{T}=0.32$} & \multicolumn{2}{|c|}{$\mathrm{S}=0.38$} & \multicolumn{2}{|c|}{$T^{\star} \mathrm{S}=0.40$} & \\
\hline \multicolumn{8}{|c|}{2010 season } \\
\hline T1 & 9.00 & 9.00 & 9.00 & 9.00 & 9.00 & 7.00 & 8.67 \\
\hline T2 & 9.00 & 9.00 & 9.00 & 9.00 & 8.33 & 7.67 & 8.67 \\
\hline T3 & 9.00 & 9.00 & 9.00 & 7.00 & 5.00 & 3.00 & 7.00 \\
\hline T4 & 9.00 & 9.00 & 9.00 & 9.00 & 7.67 & 5.00 & 8.11 \\
\hline T5 & 9.00 & 9.00 & 9.00 & 9.00 & 7.00 & 5.67 & 8.11 \\
\hline T6 & 9.00 & 9.00 & 8.33 & 6.33 & 5.00 & 3.00 & 6.78 \\
\hline T7 & 9.00 & 9.00 & 8.33 & 3.00 & 2.33 & 1.00 & 5.44 \\
\hline Mean & 9.00 & 9.00 & 8.81 & 7.48 & 6.33 & 4.62 & 7.54 \\
\hline LSD at $0.05 \%$ level & \multicolumn{2}{|c|}{$\mathrm{T}=0.30$} & \multicolumn{2}{|c|}{$\mathrm{S}=0.32$} & \multicolumn{2}{|c|}{$\mathrm{T}^{\star} \mathrm{S}=0.36$} & \\
\hline
\end{tabular}

T1= Dipping in ascorbic acid at $1 \%+$ polypropylene film.

T2=Dipping in $\mathrm{Cacl}_{2}$ at $1 \%$ then polypropylene film.

T3=Dipping in distilled + polypropylene film

T4=Dipping in ascorbic acid at $1 \%+$ stretch film

T5=Dipping in $\mathrm{Cacl}_{2} 1 \%$ +stretch film

T6=Dipping in distilled water+ with stretch film.

$\mathrm{T} 7=$ Control (without treatment)

\section{Browning:}

Browning of baby corn ears occurred at the tip of ovules and cut surface of the cob (Meenaphan, 1995). Data in Table (3) showed that development of browning increased with prolongation of the storage period. Ascorbic acid or $\mathrm{Cacl} 2$ treatment and then wrapping with different films prevented discoloration (browning the tip of ovules and silk which remained attached to the cob) as compared with ears treated with distilled water or untreated control. The AA treatment was the most effective in this concern. Oxidation of phenolic compound is the cause of browning in plant tissue (Mayer and Harel, 1991). However, changes in polyphenol oxidase activity did not show a good correlation with browning development of young - ear corn. This suggested that browning of ears might not depend on de novo synthesis of ppo activity (Meenaphan, 2003).

Successful browning inhibiting by reducing agents, ascorbic acid is attributed to the reduction of quinones back to diphenols or the reduction of $\mathrm{Cu}{ }^{2+}$ to mononuclear copper $\left(\mathrm{Cu}^{+}\right)$at the ppo active site (Suttirak and 
Manurakchinakoran 2010). Also AA or Cacl2 treatment increased AA content of baby corn ears ( Kelen et al., 2005) which is considered important for nutritional value and antioxidant properties may be reduce discoloration process. The interaction among treatments and storage period was significant in the two seasons. Baby corn ears dipped in AA solution at $1 \%$ and then wrapped with polypropylene film did not show any changes in their color till the end of the storage period. While $\mathrm{Cacl}_{2}$ at $1 \%$ treatment and wrapping with polypropylene film gave a slight score after the same period, while control treatment resulted in severe browning with the highest score.

The severe discoloration in control treatment may be due to exhibited a greater weight loss concomitant with an increase in browning and total phenolics (Meenaphan, 1995).Thus, severe weight loss of young ear corn may cause the breakdown of vacuoles and release phenolic compounds, which come into contact with pre existing ppo, resulting to quinines and finally polymerize to form browning pigments (Martinez and Whitaker, 1975).

Table (3): Effect of anti-browning agents and wrapping films on browning (score) of baby corn ears during storage in 2009 and 2010 seasons.

\begin{tabular}{|c|c|c|c|c|c|c|c|}
\hline \multirow{2}{*}{$\begin{array}{l}\text { Treatments } \\
\text { (T) }\end{array}$} & \multicolumn{7}{|c|}{ Storage period(s)/ (days) } \\
\hline & 0 & 3 & 6 & 9 & 12 & 15 & Mean \\
\hline \multicolumn{8}{|c|}{2009 season } \\
\hline T1 & 0.00 & 0.00 & 0.00 & 0.00 & 0.00 & 0.00 & 0.00 \\
\hline T2 & 0.00 & 0.00 & 0.00 & 0.00 & 0.00 & 1.00 & 0.17 \\
\hline T3 & 0.00 & 0.00 & 0.00 & 1.33 & 1.67 & 2.33 & 0.89 \\
\hline T4 & 0.00 & 0.00 & 0.00 & 0.00 & 0.00 & 1.33 & 0.22 \\
\hline T5 & 0.00 & 0.00 & 0.00 & 0.00 & 1.00 & 1.33 & 0.39 \\
\hline T6 & 0.00 & 0.00 & 0.00 & 1.00 & 2.00 & 2.67 & 0.94 \\
\hline T7 & 0.00 & 0.00 & 0.00 & 2.33 & 2.67 & 3.67 & 1.44 \\
\hline Mean & 0.00 & 0.00 & 0.00 & 0.67 & 1.05 & 1.76 & 0.58 \\
\hline LSD at $0.05 \%$ level & \multicolumn{2}{|c|}{$\mathrm{T}=0.11$} & \multicolumn{2}{|c|}{$\mathrm{S}=0.13$} & \multicolumn{2}{|c|}{$T^{\star} \mathrm{S}=0.17$} & \\
\hline \multicolumn{8}{|c|}{2010 season } \\
\hline$\overline{\mathrm{T} 1}$ & 0.00 & 0.00 & 0.00 & 0.00 & 0.00 & 0.00 & 0.00 \\
\hline T2 & 0.00 & 0.00 & 0.00 & 0.00 & 0.00 & 1.33 & 0.22 \\
\hline T3 & 0.00 & 0.00 & 0.00 & 1.67 & 2.00 & 4.00 & 1.28 \\
\hline T44 & 0.00 & 0.00 & 0.00 & 0.00 & 0.00 & 1.00 & 0.17 \\
\hline T5 & 0.00 & 0.00 & 0.00 & 0.00 & 0.00 & 1.67 & 0.28 \\
\hline T6 & 0.00 & 0.00 & 0.00 & 2.00 & 2.33 & 3.00 & 1.22 \\
\hline T7 & 0.00 & 0.00 & 1.67 & 2.33 & 3.00 & 4.00 & 1.83 \\
\hline Mean & 0.00 & 0.00 & 0.24 & 0.86 & 1.05 & 2.14 & 0.71 \\
\hline LSD at $0.05 \%$ level & \multicolumn{2}{|c|}{$\mathrm{T}=0.12$} & \multicolumn{2}{|c|}{$S=0.14$} & \multicolumn{2}{|c|}{$T^{\star} \mathrm{S}=0.19$} & \\
\hline
\end{tabular}

T1= Dipping in ascorbic acid at 1\% +polypropylene film.

T2=Dipping in $\mathrm{Cacl}_{2}$ at $1 \%$ then polypropylene film.

T3=Dipping in distilled + polypropylene film

T4=Dipping in ascorbic acid at $1 \%+$ stretch film

T5=Dipping in $\mathrm{Cacl}_{2} 1 \%+$ stretch film

T6=Dipping in distilled water+ with stretch film.

T7=Control (without treatment) 
Attia, Manal M. et al.

Color:

The color of baby corn ears was analyzed recording $L$ and $b$ values. Table (4) showed that there was a significant decrease for all treatments, indicating that the browning process of ears developed and reached darker with storage. The best results were observed for ears dipped in solution of ascorbic acid or $\mathrm{Cacl}_{2}$ then wrapped with polypropylene film, which the $\mathrm{L}$ value remained close to initial value during storage, resulted in lighter color (high $L$ value), while baby corn ears treated with distilled water and untreated (control) had darker color ( low $L$ value ). In general, values for $b$ decreased during storage for all treatment except for ascorbic acid and Cacl 2 treatments which had higher $b$ value indicating yellowing of the ears (Table 5). Indeed, with this treatment the color of baby corn ears was maintained, with significantly less browning than the other treatment. This result suggested that this treatment is a potential alternative to preserve the initial color of baby corn and protect against browning. Other work has described the influence of ascorbic acid or $\mathrm{Cacl}_{2}$ on the prevention of browning of baby corn ears (Meenaphan, 1995; Kelen et al., 2005).

Table (4): Effect of anti-browning agents and wrapping films on color ( $\mathrm{L}$ value) of baby corn ears during storage in 2009 and 2010 seasons.

\begin{tabular}{|c|c|c|c|c|c|c|c|}
\hline \multirow{2}{*}{$\begin{array}{l}\text { Treatments } \\
\text { (T) }\end{array}$} & \multicolumn{7}{|c|}{ Storage period(s)/ (days) } \\
\hline & $\mathbf{0}$ & 3 & 6 & 9 & 12 & 15 & Mean \\
\hline \multicolumn{8}{|c|}{2009 season } \\
\hline T1 & 75.14 & 73.63 & 72.23 & 70.26 & 68.43 & 67.21 & 71.15 \\
\hline T2 & 75.14 & 71.16 & 70.16 & 69.38 & 68.24 & 67.18 & 70.21 \\
\hline T3 & 75.14 & 70.56 & 67.41 & 63.41 & 61.28 & 59.64 & 66.24 \\
\hline T4 & 75.14 & 71.29 & 68.32 & 65.38 & 63.16 & 60.38 & 67.28 \\
\hline T5 & 75.14 & 72.48 & 69.51 & 64.34 & 62.81 & 61.68 & 67.66 \\
\hline T6 & 75.14 & 70.11 & 65.62 & 62.41 & 60.04 & 57.42 & 65.12 \\
\hline T77 & 75.14 & 70.28 & 64.20 & 60.23 & 58.39 & 55.18 & 63.90 \\
\hline Mean & 75.14 & 71.36 & 68.21 & 65.06 & 63.19 & 61.24 & 67.37 \\
\hline LSD at $0.05 \%$ level & \multicolumn{2}{|c|}{$\mathrm{T}=0.35$} & \multicolumn{2}{|c|}{$\mathrm{S}=0.41$} & \multicolumn{2}{|c|}{$T^{\star} S=0.43$} & \\
\hline \multicolumn{8}{|c|}{2010 season } \\
\hline T1 & 71.25 & 70.38 & 69.18 & 68.78 & 67.28 & 66.64 & 68.92 \\
\hline T2 & 71.25 & 70.68 & 68.42 & 67.19 & 66.43 & 65.54 & 68.25 \\
\hline T3 & 71.25 & 67.13 & 65.28 & 62.38 & 60.49 & 58.28 & 64.14 \\
\hline T4 & 71.25 & 68.25 & 66.64 & 64.82 & 62.01 & 61.39 & 65.73 \\
\hline T5 & 71.25 & 69.20 & 67.21 & 65.41 & 61.23 & 61.64 & 65.99 \\
\hline T6 & 71.25 & 69.15 & 64.23 & 60.50 & 58.62 & 55.14 & 63.15 \\
\hline T7 & 71.25 & 67.21 & 62.11 & 57.28 & 52.11 & 49.32 & 59.88 \\
\hline Mean & 71.25 & 68.86 & 66.15 & 63.77 & 61.17 & 59.71 & 65.15 \\
\hline LSD at $0.05 \%$ level & \multicolumn{2}{|c|}{$T=0.29$} & \multicolumn{2}{|c|}{$\mathrm{S}=0.31$} & \multicolumn{2}{|c|}{$T^{*} \mathrm{~S}=0.36$} & \\
\hline $\begin{array}{l}\text { T1= Dipping in ascor } \\
\text { T2=Dipping in Cacl } \\
\text { T3=Dipping in distille } \\
\text { T4=Dipping in ascorb } \\
\text { T5=Dipping in Cacl } 1 \\
\text { T6=Dipping in distille }\end{array}$ & $\begin{array}{l}1 \%+\text { po } \\
\text { polypro } \\
\text { opylene } \\
\% \text { + str } \\
\text { film } \\
\text { ith stre }\end{array}$ & $\begin{array}{l}\text { ypropyl } \\
\text { ylene f } \\
\text { film } \\
\text { tch film } \\
\text { ch film. }\end{array}$ & $\begin{array}{l}\text { ne film. } \\
\text { m. }\end{array}$ & & & & \\
\hline
\end{tabular}


Table (5): Effect of anti-browning agents and wrapping films on color (b value) of baby corn ears during storage in 2009 and 2010 seasons.

\begin{tabular}{|c|c|c|c|c|c|c|c|}
\hline \multirow{2}{*}{\begin{tabular}{|l}
$\begin{array}{l}\text { Treatments } \\
(\mathrm{T})\end{array}$ \\
\end{tabular}} & \multicolumn{7}{|c|}{ Storage period(s)/ (days) } \\
\hline & 0 & 3 & 6 & 9 & 12 & 15 & Mean \\
\hline \multicolumn{8}{|c|}{2009 season } \\
\hline T1 & 56.30 & 55.20 & 56.41 & 56.93 & 57.18 & 57.42 & 56.57 \\
\hline T2 & 56.30 & 56.80 & 56.90 & 57.14 & 57.42 & 57.49 & 57.01 \\
\hline T3 & 56.30 & 54.25 & 52.84 & 49.29 & 47.36 & 45.18 & 50.87 \\
\hline T4 & 56.30 & 55.23 & 54.23 & 53.42 & 52.11 & 50.38 & 53.61 \\
\hline T5 & 56.30 & 55.42 & 53.13 & 52.18 & 51.26 & 50.41 & 53.12 \\
\hline T6 & 56.30 & 53.26 & 51.04 & 48.36 & 45.28 & 43.19 & 49.57 \\
\hline T7 & 56.30 & 48.23 & 45.28 & 41.16 & 38.24 & 35.17 & 44.06 \\
\hline Mean & 56.30 & 54.06 & 52.83 & 51.21 & 49.84 & 48.46 & 52.12 \\
\hline LSD at $0.05 \%$ level & \multicolumn{2}{|c|}{$\mathrm{T}=0.31$} & \multicolumn{2}{|c|}{$\mathrm{S}=0.35$} & \multicolumn{2}{|c|}{$\mathrm{T}^{*} \mathrm{~S}=0.39$} & \\
\hline \multicolumn{8}{|c|}{2010 season } \\
\hline $\mathbf{T 1}$ & 59.41 & 59.02 & 58.64 & 58.20 & 57.80 & 57.74 & 48.70 \\
\hline T2 & 59.41 & 59.16 & 58.74 & 58.24 & 58.00 & 57.81 & 48.77 \\
\hline T3 & 59.41 & 55.16 & 54.23 & 51.00 & 49.62 & 46.11 & 43.55 \\
\hline T4 & 59.41 & 57.11 & 56.13 & 55.84 & 55.11 & 55.00 & 47.08 \\
\hline T55 & 59.41 & 58.31 & 57.15 & 56.34 & 55.61 & 54.94 & 47.44 \\
\hline T6 & 59.41 & 54.00 & 52.24 & 50.25 & 47.11 & 43.16 & 42.32 \\
\hline T7 & 59.41 & 55.63 & 50.62 & 46.19 & 40.28 & 35.41 & 39.49 \\
\hline Mean & 59.41 & 56.91 & 55.39 & 53.72 & 51.93 & 50.02 & 45.33 \\
\hline LSD at $0.05 \%$ level & \multicolumn{2}{|c|}{$\mathrm{T}=\mathbf{0 . 3 2}$} & \multicolumn{2}{|c|}{$\mathrm{S}=0.34$} & \multicolumn{2}{|c|}{$\mathrm{T}^{\star} \mathrm{S}=0.38$} & \\
\hline
\end{tabular}

T1= Dipping in ascorbic acid at $1 \%$ +polypropylene film.

T2=Dipping in $\mathrm{Cacl}_{2}$ at $1 \%$ then polypropylene film.

T3=Dipping in distilled + polypropylene film

T4=Dipping in ascorbic acid at $1 \%$ + stretch film

T5=Dipping in $\mathrm{Cacl}_{2} 1 \%+$ stretch film

T6=Dipping in distilled water+ with stretch film.

T7=Control (without treatment)

\section{Total phenolic content:}

Data in Table (6) showed that total phenolic content decreased with prolongation of storage period. The decrease of this content is probably due to the oxidation of phenolic compounds by contact with preexisting ppo (Meenaphan, 2003), Moreover, Robards et al. (1999) found that phenolic compounds have a significant role in oxidation processes as antioxidents and as substrates in browning reaction.

Baby corn ears treated with ascorbic acid or $\mathrm{Cacl}_{2}$ then wrapped with different films were the most effective treatment in maintaining of total phenolic compounds compared with immersion in distilled water or untreated control. Wrapping with stretch film was less effective than polypropylene film. These results agree with those obtained by Meenphan (2003) who found that the rate of degradation of individual phenolic compounds decreased in baby corn ears during storage when ascorbic acid or $\mathrm{Cacl}_{2}$ were added. Acidification of samples appeared to have an important function to stabilize phenolic compounds in baby corn ears. 
Attia, Manal M. et al.

The interaction of treatments and storage period was significant. The lowest value of total phenolic compounds at the end of storage period (15 days) was noted in control treatment.

Table (6): Effect of anti-browning agents and wrapping films on total phenolic content (gm /100gm F.W) of baby corn ears during storage in 2009 and 2010 seasons.

\begin{tabular}{|l|c|c|c|c|c|c|c|}
\hline \multirow{2}{*}{$\begin{array}{l}\text { Treatments } \\
\text { (T) }\end{array}$} & 0 & 3 & 6 & 9 & 12 & 15 & Mean \\
\hline \multicolumn{7}{|c|}{2009 season } \\
\hline T1 & 18.24 & 18.01 & 17.72 & 17.20 & 16.30 & 14.95 & 17.07 \\
\hline T2 & 18.24 & 17.94 & 17.62 & 17.00 & 16.35 & 15.41 & 17.09 \\
\hline T3 & 18.24 & 17.64 & 16.80 & 16.04 & 14.82 & 13.60 & 16.19 \\
\hline T4 & 18.24 & 17.80 & 17.32 & 16.80 & 15.73 & 14.40 & 16.72 \\
\hline T5 & 18.24 & 17.62 & 17.00 & 16.58 & 15.48 & 14.33 & 16.54 \\
\hline T6 & 18.24 & 17.34 & 16.52 & 15.84 & 14.52 & 13.40 & 15.98 \\
\hline T7 & 18.24 & 17.00 & 16.13 & 15.20 & 13.26 & 12.36 & 15.37 \\
\hline Mean & 18.24 & 17.62 & 17.02 & 16.38 & 15.21 & 14.06 & 16.42 \\
\hline LSD at 0.05 \% level & T=0.16 & S=0.21 & $T^{\star} \mathrm{S}=0.28$ & \\
\hline \multicolumn{7}{|c|}{2010 season } \\
\hline T1 & 20.13 & 16.24 & 15.62 & 15.10 & 14.10 & 13.00 & 15.70 \\
\hline T2 & 20.13 & 15.81 & 15.74 & 15.11 & 14.24 & 13.20 & 15.71 \\
\hline T3 & 20.13 & 15.52 & 14.74 & 14.00 & 12.93 & 11.70 & 14.84 \\
\hline T4 & 20.13 & 15.71 & 15.20 & 14.72 & 13.75 & 12.53 & 15.34 \\
\hline T5 & 20.13 & 15.73 & 15.17 & 14.67 & 13.54 & 12.25 & 15.25 \\
\hline T6 & 20.13 & 15.57 & 14.62 & 13.92 & 12.67 & 11.52 & 14.74 \\
\hline T7 & 20.13 & 15.14 & 14.00 & 13.17 & 11.17 & 12.42 & 14.34 \\
\hline Mean & 20.13 & 15.67 & 15.01 & 14.38 & 13.20 & 12.37 & 15.13 \\
\hline LSD at $0.05 \%$ level & T=0.16 & \multicolumn{7}{|c|}{ S=0.19 } & $T^{\star} \mathrm{S}=0.25$ & \\
\hline
\end{tabular}

T1= Dipping in ascorbic acid at $1 \%$ +polypropylene film.

T2=Dipping in $\mathrm{Cacl}_{2}$ at $1 \%$ then polypropylene film.

T3=Dipping in distilled + polypropylene film

T4=Dipping in ascorbic acid at $1 \%$ + stretch film

T5=Dipping in $\mathrm{Cacl}_{2} 1 \%+$ stretch film

T6=Dipping in distilled water+ with stretch film.

T7=Control (without treatment)

\section{Poly phenol oxidase activity (ppo):}

Data in Table (7) showed that ppo activity of baby corn ears was the greatest on day 0 and slightly increased with the prolongation of the storage period. Baby corn ears dipping in solution of $1 \%$ ascorbic acid or $1 \% \mathrm{Cacl}_{2}$ and then wrapped with polypropylene film were reduced ppo activity compared with anti-browning treatment and wrapping with stretch film or untreated (control). Ascorbic acid treatment then wrapping with polypropylene film was the most effective treatment in reducing ppo activity during storage.

Ascorbic acid or $\mathrm{Cacl}_{2}$ have been reported expensively for their inhibitory effect on ppo. Meenaphan (1995) found that ascorbic acid is reducing compound but it does not directly inhibit ppo. Following enzymatic oxidation, AA reduced the 6- quinine formed by the enzyme to the original diphenol to limit browning through a process known as reaction deactivation or the reduction of $\mathrm{Cu}^{2+}$ to mononuclear $\mathrm{Cu}^{2+}$ at the ppo active site (Suttirak and Manurakchinakorn, 2010). Also calcium reduced ppo activity through 
complication the copper at the active site of the enzyme (Bolin and Huxsoll, 1989).

Table (7): Effect of anti-browning agents and wrapping films on poly phenol oxidase activity \% of baby corn ears during storage in 2009 and 2010 seasons.

\begin{tabular}{|c|c|c|c|c|c|c|c|}
\hline \multirow{2}{*}{$\begin{array}{l}\text { Treatments } \\
(\mathrm{T})\end{array}$} & \multicolumn{7}{|c|}{ Storage period(s)/ (days) } \\
\hline & 0 & 3 & 6 & 9 & 12 & 15 & Mean \\
\hline \multicolumn{8}{|c|}{2009 season } \\
\hline $\mathrm{T1}$ & 100.06 & 101.62 & 102.45 & 104.18 & 106.16 & 108.24 & 103.79 \\
\hline T2 & 100.06 & 100.68 & 101.24 & 104.31 & 106.20 & 107.13 & 103.27 \\
\hline T3 & 100.06 & 103.68 & 105.56 & 107.48 & 111.25 & 113.64 & 106.95 \\
\hline $\mathbf{T 4}$ & 100.06 & 102.11 & 103.25 & 105.24 & 109.34 & 111.43 & 105.24 \\
\hline T55 & 100.06 & 102.36 & 104.21 & 106.15 & 110.32 & 111.31 & 105.74 \\
\hline T6 & 100.06 & 102.64 & 105.89 & 108.26 & 111.98 & 114.25 & 107.18 \\
\hline T7 & 100.06 & 104.82 & 107.79 & 110.98 & 114.24 & 116.96 & 109.14 \\
\hline Mean & 100.06 & 102.56 & 104.34 & 106.66 & 109.93 & 111.85 & 105.90 \\
\hline LSD at $0.05 \%$ level & \multicolumn{2}{|c|}{$\mathrm{T}=0.23$} & \multicolumn{2}{|c|}{$\mathrm{S}=0.27$} & \multicolumn{2}{|c|}{$\mathrm{T}^{*} \mathrm{~S}=0.31$} & \\
\hline \multicolumn{8}{|c|}{2010 season } \\
\hline T1 & 99.21 & 101.62 & 103.41 & 104.23 & 106.41 & 107.32 & 103.70 \\
\hline T2 & 99.21 & 100.61 & 101.35 & 103.25 & 107.31 & 108.26 & 103.33 \\
\hline T3 & 99.21 & 102.26 & 104.68 & 106.78 & 111.45 & 112.67 & 106.18 \\
\hline T4 & 99.21 & 101.82 & 103.79 & 105.97 & 108.92 & 111.35 & 105.18 \\
\hline T5 & 99.21 & 101.64 & 103.25 & 106.36 & 110.51 & 111.81 & 105.46 \\
\hline T6 & 99.21 & 103.26 & 105.74 & 107.69 & 113.54 & 114.98 & 107.40 \\
\hline T7 & 99.21 & 104.92 & 108.51 & 112.62 & 115.81 & 118.78 & 109.98 \\
\hline Mean & 99.21 & 102.30 & 104.39 & 106.70 & 110.56 & 112.17 & 105.89 \\
\hline LSD at $0.05 \%$ level & \multicolumn{2}{|c|}{$\mathrm{T}=0.20$} & \multicolumn{2}{|c|}{$\mathrm{S}=0.23$} & \multicolumn{2}{|c|}{$T^{\star} \mathrm{S}=0.29$} & \\
\hline \multicolumn{8}{|c|}{$\begin{array}{l}\text { T1= Dipping in ascorbic acid at } 1 \%+\text { polypropylene film. } \\
\text { T2=Dipping in } \text { Cacl }_{2} \text { at } 1 \% \text { then polypropylene film. } \\
\text { T3=Dipping in distilled + polypropylene film } \\
\text { T4=Dipping in ascorbic acid at } 1 \%+\text { stretch film } \\
\text { T5=Dipping in Cacl } 1 \%+\text { stretch film } \\
\text { T6=Dipping in distilled water+ with stretch film. } \\
\text { T7=Control (without treatment) }\end{array}$} \\
\hline
\end{tabular}

\section{Total microbial count:}

Data in Table (8) showed that microbial growth was increased with increasing the storage period particularly in control treatment. All treatments used had lower level of microbial load in comparison to control treatment. However, baby corn ears treated with ascorbic acid $1 \%$ or $\mathrm{Cacl}_{2} 1 \%$ and then wrapped with polypropylene film was the most effective treatment for reduction total microbial count. Ascorbic acid treatment was less effective than $\mathrm{Cacl}_{2}$ in reducing this character. These results are in agreement with those obtained by Kelen et al. (2005) who found that calcium or ascorbic acid treatments may have provided an inhibitory effect on microbial growth, while control treatment allowed for spore spreading and actually increased counts. Calcium salts can lower intracellular pH or reduce water activity (Shelf, 1994) which provides a protective antimicrobial barrier against food born pathogens in products (Weaver and Shelef, 1993). Also micro flora is usually restricted 
Attia, Manal M. et al.

to fungal and lactic acid bacteria when $\mathrm{pH}$ was low (Luna.Guzman and Barrett, 2000). Also calcium could enhance tissue to fungal or bacterial attack by stabilizing or strengthening cell walls (Bolin and Huxsoll, 1989).

The same data revealed that the immersion of baby corn in distilled water and wrapped with different films lower the total microbial count than control. The interaction between treatments and storage period were significant in the two seasons.

Table (8): Effect of anti-browning agents and wrapping films on total microbial count (log $10 \mathrm{CFU}$ ) of baby corn ears during storage in 2009 and 2010 seasons.

\begin{tabular}{|c|c|c|c|c|c|c|c|}
\hline \multirow{2}{*}{$\begin{array}{l}\text { Treatments } \\
\text { (T) }\end{array}$} & \multicolumn{7}{|c|}{ Storage period(s)/ (days) } \\
\hline & 0 & 3 & 6 & 9 & 12 & 15 & Mean \\
\hline \multicolumn{8}{|c|}{2009 season } \\
\hline$\overline{\mathrm{T} 1}$ & 0.54 & 1.52 & 1.95 & 1.98 & 2.16 & 2.24 & 1.73 \\
\hline T2 & 0.54 & 1.31 & 1.68 & 1.74 & 1.92 & 2.06 & 1.54 \\
\hline T3 & 0.54 & 1.98 & 2.24 & 2.48 & 3.03 & 3.68 & 2.33 \\
\hline T4 & 0.54 & 1.62 & 2.13 & 2.25 & 2.54 & 2.78 & 1.98 \\
\hline T5 & 0.54 & 1.58 & 1.75 & 2.10 & 2.32 & 2.51 & 1.80 \\
\hline T6 & 0.54 & 1.94 & 2.35 & 2.78 & 3.35 & 3.96 & 2.49 \\
\hline T7 & 0.54 & 2.25 & 2.59 & 3.04 & 3.82 & 4.25 & 2.75 \\
\hline Mean & 0.54 & 1.74 & 2.10 & 2.34 & 2.73 & 3.07 & 2.09 \\
\hline LSD at $0.05 \%$ level & \multicolumn{2}{|c|}{$\mathrm{T}=0.11$} & \multicolumn{2}{|c|}{$\mathrm{S}=0.16$} & \multicolumn{2}{|c|}{$T^{\star} S=0.20$} & \\
\hline \multicolumn{8}{|c|}{2010 season } \\
\hline T1 & 0.46 & 1.04 & 1.16 & 1.38 & 1.79 & 2.00 & 1.31 \\
\hline T2 & 0.46 & 0.67 & 0.82 & 1.04 & 1.53 & 1.82 & 1.06 \\
\hline T3 & 0.46 & 1.27 & 1.35 & 1.57 & 1.92 & 2.35 & 1.49 \\
\hline T4 & 0.46 & 1.17 & 1.26 & 1.52 & 1.94 & 2.15 & 1.42 \\
\hline T5 & 0.46 & 0.92 & 1.20 & 1.30 & 1.69 & 1.98 & 1.26 \\
\hline T6 & 0.46 & 1.34 & 1.48 & 1.67 & 2.10 & 2.48 & 1.59 \\
\hline T7 & 0.46 & 1.57 & 1.92 & 2.41 & 2.92 & 3.97 & 2.21 \\
\hline Mean & 0.46 & 1.14 & 1.31 & 1.56 & 1.98 & 2.39 & 1.47 \\
\hline LSD at $0.05 \%$ level & \multicolumn{2}{|c|}{$\mathrm{T}=0.13$} & \multicolumn{2}{|c|}{$\mathrm{S}=0.16$} & \multicolumn{2}{|c|}{$\mathrm{T}^{\star} \mathrm{S}=0.21$} & \\
\hline
\end{tabular}

T1= Dipping in ascorbic acid at $1 \%$ +polypropylene film.

T2=Dipping in $\mathrm{CaCl}_{2}$ at $1 \%$ then polypropylene film.

T3=Dipping in distilled + polypropylene film

T4=Dipping in ascorbic acid at $1 \%+$ stretch film

T5=Dipping in $\mathrm{Cacl}_{2} 1 \%+$ stretch film

T6=Dipping in distilled water+ with stretch film.

$\mathrm{T} 7=$ Control (without treatment)

\section{Total sugars:}

Data in Table (9) showed that total sugar content of baby corn ears was decreased as the storage period was extended. These results are in agreement with those obtained by Attia (2006) and might be due to the consumption of sugars through respiration.

However, all treatments reduced the total sugar loss as compared with control, while dipping baby corn ears in ascorbic acid or $\mathrm{Cacl}_{2}$ and then wrapping with polypropylene film seems to be the most effective in reducing the total sugar loss. Anti-browning treatments and wrapping with stretch film were less effective in this concern. Meenaphan (1995) found that dipping baby corn ears in ascorbic acid or $\mathrm{Cacl}_{2}$ induced a delay in consumption of 
sugar. The interaction between treatments and storage period was significant.

Table (9): Effect of anti-browning agents and wrapping films on total sugars\% (gm/100gm F.W) of baby corn ears during storage in 2009 and 2010 seasons.

\begin{tabular}{|c|c|c|c|c|c|c|c|}
\hline \multirow{2}{*}{$\begin{array}{l}\text { Treatments } \\
\text { (T) }\end{array}$} & \multicolumn{7}{|c|}{ Storage period(s)/ (days) } \\
\hline & 0 & 3 & 6 & 9 & 12 & 15 & Mean \\
\hline \multicolumn{8}{|c|}{2009 season } \\
\hline T1 & 10.92 & 10.72 & 10.53 & 10.00 & 9.71 & 9.44 & 10.22 \\
\hline T2 & 10.92 & 10.82 & 10.74 & 10.11 & 9.65 & 9.68 & 10.32 \\
\hline$\overline{T 3}$ & 10.92 & 10.42 & 10.11 & 9.72 & 9.34 & 8.05 & 9.76 \\
\hline T44 & 10.92 & 10.31 & 10.22 & 9.80 & 9.23 & 8.56 & 9.84 \\
\hline T5 & 10.92 & 10.51 & 10.32 & 9.90 & 9.32 & 8.64 & 9.94 \\
\hline T6 & 10.92 & 10.31 & 9.80 & 9.32 & 8.64 & 7.90 & 9.48 \\
\hline T7 & 10.92 & 10.02 & 9.42 & 8.66 & 7.92 & 7.11 & 9.01 \\
\hline Mean & 10.92 & 10.44 & 10.16 & 9.64 & 9.12 & 8.48 & 9.80 \\
\hline LSD at $0.05 \%$ level & \multicolumn{2}{|c|}{$\mathrm{T}=0.19$} & \multicolumn{2}{|c|}{$\mathrm{S}=0.21$} & \multicolumn{2}{|c|}{$T^{\star} \mathrm{S}=0.26$} & \\
\hline \multicolumn{8}{|c|}{2010 season } \\
\hline $\mathbf{T} 1$ & 11.23 & 11.13 & 10.82 & 10.51 & 10.30 & 10.04 & 10.67 \\
\hline T2 & 11.23 & 11.10 & 10.91 & 10.50 & 10.42 & 10.18 & 10.72 \\
\hline T3 & 11.23 & 10.73 & 10.30 & 9.65 & 9.03 & 8.60 & 9.92 \\
\hline T4 & 11.23 & 10.92 & 10.51 & 10.16 & 9.54 & 9.08 & 10.24 \\
\hline T5 & 11.23 & 11.00 & 10.62 & 10.20 & 9.50 & 9.00 & 10.26 \\
\hline T6 & 11.23 & 10.53 & 10.10 & 9.40 & 8.82 & 8.40 & 9.75 \\
\hline T7 & 11.23 & 10.30 & 9.89 & 9.64 & 8.70 & 8.00 & 9.63 \\
\hline Mean & 11.23 & 10.82 & 10.45 & 10.01 & 9.47 & 9.04 & 10.17 \\
\hline LSD at $0.05 \%$ level & \multicolumn{2}{|c|}{$\mathrm{T}=0.16$} & \multicolumn{2}{|c|}{$\mathrm{S}=0.20$} & \multicolumn{2}{|c|}{$T^{\star} \mathrm{S}=0.27$} & \\
\hline
\end{tabular}

T1= Dipping in ascorbic acid at $1 \%$ +polypropylene film.

T2=Dipping in $\mathrm{Cacl}_{2}$ at $1 \%$ then polypropylene film.

T3=Dipping in distilled + polypropylene film

T4=Dipping in ascorbic acid at $1 \%+$ stretch film

T5=Dipping in $\mathrm{Cacl}_{2} 1 \%+$ stretch film

T6=Dipping in distilled water+ with stretch film.

T7=Control (without treatment)

\section{Conclusion}

Baby corn ears dipping in solution of ascorbic acid at $1 \%$ or $\mathrm{Cacl}_{2}$ at $1 \%$ and then wrapping with poly propylene film was the most effective treatment in inhibiting browning on ears (indicating by higher $L$ value and $b$ value), maintained quality and gave ears with good appearance for 15 days at $5{ }^{\circ} \mathrm{C}$ and $95 \% \mathrm{RH}$. 


\section{REFERENCES}

Anese,M.M and M.C. Nicoli (1997).Quality of minimally processed apple slice using different modified atmosphere conditions. J.Food Quality, 20:359 -370 .

AOAC(1990).Official Methods of Analysis .13 th Ed. Association of Official Chemists Washington DC. USA.

Attia , M.M (2006). Effect of some pre and postharvest treatments on quality of sweet corn. Ph.D thesis. Faculty of Agriculture (Horticulture), Ain Shams University.

Bolin, H.R. and C.C.Huxsoll (1989).Storage stability of minimally processed fruit. J. Food Processing Preservation,13: 281- 292.

Burton, W.G.(1982).Post- harvest physiology of food crops. Longman Group Ltd.,London.

Deak,T., E.K. Heaton, Y.C. Hung and L.R. Beuchat.(1987).Extending the shelf life of fresh sweet corn by shrink- wrapping, refrigeration, and irradiation. J. Food Sci. 52: 1625 - 1631.

Dogan, M., O. Aslan and S. Dogan (2002).Substrate specificity, heat inactivation and inhibition of polyphenol oxidase from different aubergine cultivars. Interm. J.Food Sci. Technol.,37: 415- 423.

Gonzalez- Aguilar, G.A.J.F.Ayala- Zavala, S.Ruiz-Cruz,E.Acedo-Felix and M.E.Diaz-Cinco (2004). Effect of temperature and modified atmosphere packaging on overall quality of fresh-cut bell pepper Lebensm-Wiss, U- Technol.37:817-826.

Hardenburg, R.E., A.E.Watada and C.Y.Wang (1986).The commercial storage of fruits and vegetables and florist and nursery stocks.USDA, Hdbk.66.

Kelen, C.D.R., J.Pereira,L.C.O.lima,R.G.Pinho and A.R.Morais (2005). Application of calcium lactate in the conservation of baby corn minimally processed. Ciênc. agrotec., Lavras, v. 29 , n. 2, p. 338-345, mar./abr., 2005338-345.

Lee, J.Y., H.J.Park, C.Y. Lee and W.Y.Choi (2003).Extending shelf - life of minimally processed apples with edible coating and antibrowning agents. Lebensm. Wiss. Technol.36; 323-329.

Luna-Guzman, I. and D.M.Barrett (2000). Comparison of calcium chloride and calcium lactate effectiveness in maintaining shelf stability and quality of fresh- cut cantaloupe. Postharvest Biol. Technol. 19 : 61 72.

Martinez, M.V. and J.R. Whitaker (1995).The biochemistry and control of enzymatic browning. Trends in Food Sci.Technol.6: 195 - 200.

Mayer, A.M. and E. Harel (1991). Polyphenoloxidase and their significance in fruit and vegetables In P.F. Fox, ed., Food Enzymology, v.l, Elsevier, London pp.373 -398.

Meenaphan,A.(1995). Control of postharvest browning and decay in baby corn.Summary of dissertation. Thai.National AGRIS Centre, Main Library, Kasetsart University (Thailand). 
Meenaphan, A. and S.Kesta (2003). Browning of baby corn after harvest. Acta Hort. 628: $569-574$

Nelson, N. (1974). A photometric adaptation of Somogyi methods for Determination of glucose. J. Biology Chem., 159: $375-380$.

Risse , L.A. and R.E.McDonald(1990). Quality of supersweet corn film overwrapped in trays. HortScinece .25 (3):322 - 324.

Robards, K., P.D. Prenzle,G. Tucker, P.Swatsitang and W.Solver (1999). Phenolic compounds and theire role in oxidative processes in Fruits. Food Chemistry, 66 (4): $401-436$.

Robinson,J.E.,K.M.Browne and W.G.Burton.(1975).Storage characteristics of some vegetables and soft fruits. Ann Appl.Biol. 81:399- 408.

Rodov, V.,A.Copel, N.Aharoni,Y.Aharoni, A.Wiseblum,B.Horev and Y. Vinokur.(2000). Nested modified - atmosphere packages maintain quality of trimmed sweet corn during cold storage and the shelf life period. Postharvest Biol. Technol. 18: 259- 266.

Shelef,L.A.(1994).Antimicrobial effects of lactates: a review. J.Food Prot.,57: 445- 450.

Showalter, R.K. (1967). Sweet corn shelf- life as affected by trimming and packaging. Amer. Soc. Hort. Sci. $91881-884$.

Snedecor, G. W. and W. G. Cochran (1980).Statistical methods. lowa State Univ. Press, USA.

Somogyi, M. (1952).Notes on sugar determination, Jour. Biology Chem., 195: 19-23.

Son,S.M., K.D.Moon and C.Y. Lee.(2001). Inhibitory effects of various antibrowning agents on apple slices. Food Chem. 73, 23 -30.

Suttirak, w. and S. Manurakchinakorn (2010). Potential application of ascorbic acide, citric acid and oxalic acid for browning inhibition in fresh - cut fruits and vegetables.walailak J Sci\& Tech 7 (1): 5 - 14 .

Wang,Z., M.Stone and E.Gray (2010). Effect of different schedules of baby corn (zez mays L.) Harvests on baby corn yield, grain yield, and economic return.J.Kentucky Acad.Sci. 71:59-66

Weaver,R.A. and L.A. Shelef (1993). Antilisterial activity of sodium, potassium or calcium lactates in pork liver sausage. J.Food Safety 13, $133-146$. 
Attia, Manal M. et al.

تأثير استخدام مضادات التلون البنى والمغلفات على تقليل التلون البنى والاحتفاظ بالجودة فى الأرة البيبى خلادل مدات التخزين.

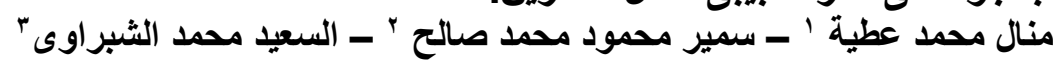

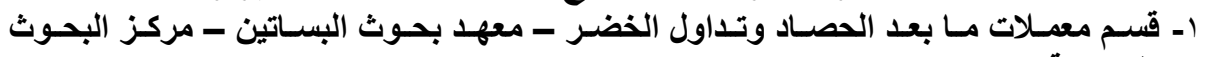

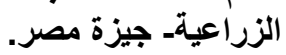

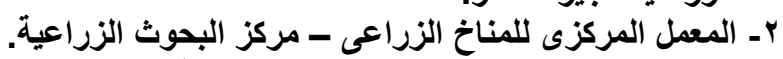

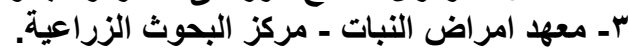

تم زر اعة الذرة البيبى (الهجين الثلاثى (بT) ) بمحطة|لتجارب الزر اعية بقها - محافظة القليوبية

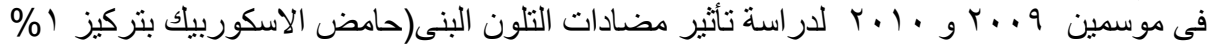

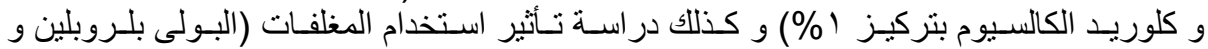

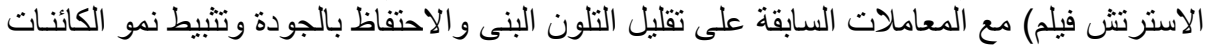

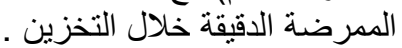

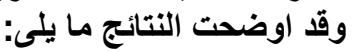

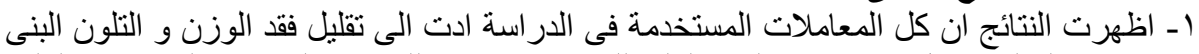

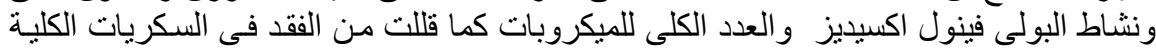

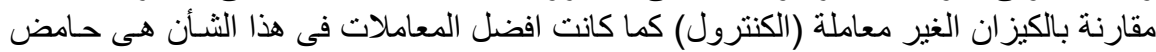

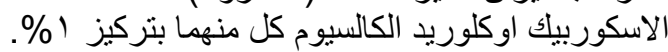

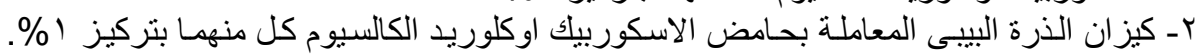

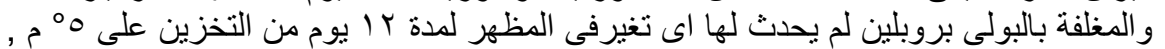

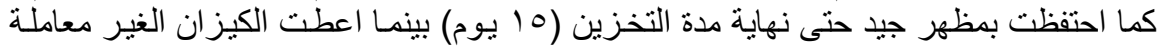
مظهر ضعيف بعد 9 ايام فقط من التخزين.

كلية الزراعة - جامعة المنصورة مركز البحوث الزراعية

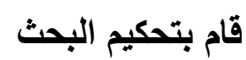

أ. أد / سمير طنه محمود العفيفى

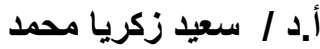

